\title{
Systematic Review: Guideline-Based Approach for the Management of Asthma and Subtypes via Chinese Medicine
}

\author{
Lin Ho Wong $\mathbb{D}^{1,},{ }^{1,2}$ Louisa Tay, ${ }^{2}$ Robby Miguel W. J. Goh, ${ }^{3}$ Tai Joum Tan, ${ }^{3}$ Ruishu Zhou, ${ }^{2}$ \\ Aaron Kwun Hang Ho, ${ }^{4}$ and Pang Ong Wong ${ }^{1,5}$
}

${ }^{1}$ Ong Fujian Chinese Physician Hall, Singapore

${ }^{2}$ Singapore College of Traditional Chinese Medicine, Singapore

${ }^{3}$ University College London, London, UK

${ }^{4}$ Ministry of Health Holdings, Singapore

${ }^{5}$ Chang Chun University of Traditional Chinese Medicine, Changchun, China

Correspondence should be addressed to Lin Ho Wong; nate.wong90@live.com.sg

Received 9 June 2020; Accepted 30 December 2020; Published 7 January 2021

Academic Editor: Vincenzo De Feo

Copyright (c 2021 Lin Ho Wong et al. This is an open access article distributed under the Creative Commons Attribution License, which permits unrestricted use, distribution, and reproduction in any medium, provided the original work is properly cited.

\begin{abstract}
Background. Asthma is a chronic condition that results in the inflammation and narrowing of airways, often clinically presenting as wheeze and shortness of breath. Little is known of the mechanisms of action (MOA) of herbs used to treat asthma. The aim of this study is to review existing data regarding known MOA of traditional Chinese medicine which will aid in the understanding of possible interactions between Western drugs and Chinese herbs as well as the standardization of management via a proposed guideline to improve patient safety and possible synergism in the long term. Methods. We searched through 5 databases for commonly prescribed herbs and formulas for asthma and narrowed down the search to identify the underlying MOA of individual herbs that could specifically target asthma symptoms. We included studies that stated the MOA of individual herbs when used for treating symptoms of asthma, excluding them if they are described as part of a formula. Results. A total of 26 herbs commonly prescribed for asthma with known mechanism of action were identified. Herbs used for asthma were found to have similar MOA as that for drugs. Based on existing GINA guidelines, a guideline is proposed which includes a total of 5 steps depending on the severity of asthma and the herbs' MOA. 16 formulas were subsequently identified for the management of asthma, which consist of 12 "stand-alone" and 4 "add-on" formulas. "Stand-alone" formulas used independently for asthma generally follow the GINA guidelines but do not proceed beyond step 3. These formulas consist mainly of beta-agonist and steroid-like effects. "Add-on" formulas added as adjunct to "stand-alone" formulas, however, mainly act on T helper cells or have steroid-like effects. Conclusion. Through the understanding of MOA of herbs and their respective formulas, it will ensue greater patient safety and outcomes.
\end{abstract}

\section{Introduction}

There has been an increasing trend in the use of complementary and alternative medicine (CAM) [1] since its acknowledgement by the World Health Organization (WHO) in 2018 [2]. Herbs are being used by $75 \%$ of the people in the world for their basic healthcare needs [3]. Despite the dominance of Western evidence-based medicine in healthcare settings, people occasionally seek traditional Chinese medicine (TCM) treatments, a widely used form of CAM, for medical conditions such as chronic pain and allergies, including, but not limited to, asthma.
Asthma is a heterogeneous disease that is characterized by chronic, reversible airway inflammation that involves eosinophil granulocytes, mast cells, T cells, and an array of cytokines. As curative treatments for asthma are still not available, patients are increasingly seeking CAM for add-on treatments, resulting in growing concerns over the concomitant use of Western medicine and CAM herbs [4]. Furthermore, most CAM herbs used for asthma have unknown mechanism of actions (MOA). This could potentially lead to dangerously high concentration of constituents with the same MOA, which may lead to severe side effects. 
While Western doctors typically manage asthma using the Global Initiative for Asthma (GINA) guidelines based on the disease severity, TCM adopts a less guideline-based and more individualized therapy via a holistic view of the patient's pathophysiology, resulting in a discrepancy in herbal prescribing between TCM physicians [5]. With increasing scientific evidence to support the use of TCM for asthma [6], it is crucial for both medical doctors and TCM physicians to be aware of the potential risks that come with the simultaneous use of prescribed drugs and herbal medicine.

This review aims to categorise commonly used herbs and empirical prescriptions of TCM based on known MOA of Western medicines to allow both Western and TCM physicians to have a better understanding of how drugs and herbs interact. This will hopefully lead to increased patient safety and possible synergism in the long run, giving patients more choices for an individually tailored treatment and better treatment outcomes.

\section{Methods}

\subsection{Criteria for considering Studies for This Review}

2.1.1. Types of Studies. All studies eliciting the mechanism of action of a specific herb in the context of asthma, regardless of the model. Studies which involved the use of multiple herbs simultaneously (i.e., formulas) were excluded.

\subsection{Search Methods for Identification of Studies}

2.2.1. Electronic Searches. For this review, we searched EMBASE, PubMed, CENTRAL, Wanfang, and China National Knowledge Infrastructure (CNKI).

2.3. Identifying the Herbs. We first conducted a search to identify herbs which are currently commonly prescribed by TCM physicians by identifying systematic reviews on frequently used herbs or formulas and extracted the relevant herbs from the formulas, using the terms "asthma AND TCM OR Traditional Chinese Medicine OR alternative medicine" in EMBASE, PubMed, CENTRAL, Wanfang, and CNKI (Figure 1). The list was subsequently confirmed with a senior TCM physician specialising in TCM Formula-logy.

We then extracted the Latin and Mandarin names of the herbs used and identified those used primarily for the treatment of asthma, before searching electronic databases for their mechanisms of action (Figure 2). Herbs prescribed for supportive treatment were excluded.

\subsection{EMBASE, PubMed, and Cochrane}

2.4.1. CNKI (Overseas CNKI) and Wanfang (Based on the Translations of the Keywords Used in English Medium)

(1) "Glycyrrhiza uralensis" AND "asthma”

(2) "Prunus armeniaca" AND "asthma"
(3) "Pinellia ternata" AND "asthma"

(4) "Asarum sieboldii" AND "asthma"

(5) "Pheretima aspergillum" AND "asthma"

(6) "Aster tataricus" AND "asthma"

(7) "Fritillaria cirrhosa" AND "asthma"

(8) "Lepidium apetalum" AND "asthma"

(9) "Pericarpium Citri Reticulatae" AND "asthma"

(10) "Cortex Mori" AND "asthma"

(11) "Ephedra sinica" AND "asthma”

(12) "Zingiber officinale" AND "asthma"

(13) “Tussilago farfara" AND "asthma”

(14) "Platycodon grandifloras" AND "asthma"

(15) "Fritillaria thunbergii" AND "asthma"

(16) "Paeonia lactiflora" AND "asthma"

(17) "Magnolia officinalis" AND "asthma"

(18) "Bupleurum chinense" AND "asthma"

(19) "Scutellaria baicalensis" AND "asthma"

(20) "Perilla frutescens" AND "asthma"

(21) "Anemarrhena Rhizoma" AND “asthma”

(22) "Gypsum fibrosum" AND "asthma"

(23) "Eriobotryae Folium" AND "asthma"

(24) "Cinnamomi Ramulus" AND “asthma”

(25) "Zingiberis rhizoma" AND "asthma"

(26) "Schisandra Fructus" AND "asthma"

We did not impose any language or publication restrictions.

\subsection{Data Collection and Analysis}

2.5.1. Selection of Studies. Four review authors (TJ, L, RS, and RM) independently reviewed the titles, abstracts, and keywords of all records retrieved to determine the studies to be assessed. We retrieved full articles for further assessment if the information given suggested that the study:

(1) Discussed asthma

(2) And administered any of 26 Chinese herbs identified through the initial search

A fifth review author $(\mathrm{LH})$ acted as arbiter and resolved any differences in opinion.

2.5.2. Data Analysis. We first identified the herbs relevant to treating asthma by the formulas which contain them, for reference purposes (Table 1). We then categorised the herbs according to their mechanisms of action (Table 2), plotted a schematic representation of the herbs on the asthma immunopathological pathway (Figure 3), and then compared them against GINA guidelines to identify clinical situations where herbs could see the potential use (Figure 4). 


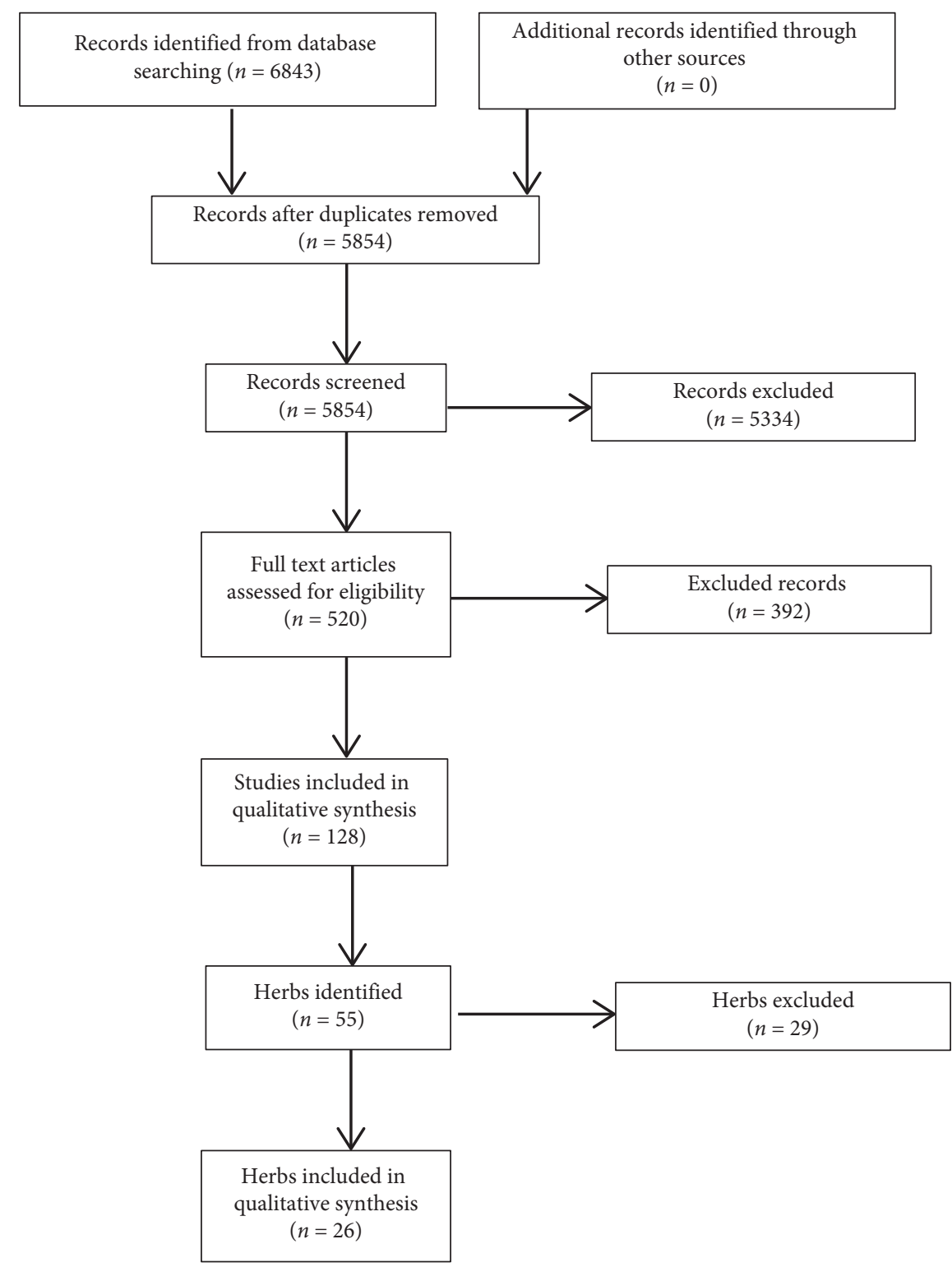

FIgURE 1: Study flow diagram of the identification of commonly used herbs for asthma.

\section{Results}

3.1. Results of the Search to Identify Herbs of Interest. Our initial searches in online databases identified 6843 studies, of which 128 systematic reviews were relevant to our topic, yielding 55 herbs (Figure 1).

3.2. Included Herbs. Of the 55 herbs, 26 were used primarily for asthma treatment.

These included Glycyrrhiza uralensis [7-24], Prunus armeniaca [25, 26], Pinellia ternata [27], Asarum sieboldii [28, 29], Pheretima aspergillum [30-37], Aster tataricus [38, 39], Fritillaria cirrhosa [40-43], Lepidium apetalum [44], Pericarpium Citri Reticulatae [45-47], Cortex Mori [48-52], Ephedra sinica Stapf [53-56], Zingiber officinale Roscoe [57], Tussilago farfara [58-61], Platycodon grandifloras [62-65], Fritillaria thunbergii [66, 67], Paeonia lactiflora [68-71], Magnolia officinalis [72-77], Bupleurum chinense [78, 79], Scutellaria baicalensis [80-86], Anemarrhena Rhizoma [87, 88], Gypsum fibrosum, Eriobotryae Folium [89], Cinnamomi Ramulus [90], Zingiberis rhizoma, Schisandra Fructus [91-93], and Perilla frutescens [94].

\subsection{Results of the Search for Herb Mechanisms of Action}

3.3.1. Included Studies. Searching online databases yielded 8961 studies, of which 149 met the inclusion criteria (Figure 2). No studies were found for the herbs Gypsum fibrosum and Zingiberis rhizoma.

3.3.2. Mechanisms of Action. We first extracted the proposed mechanisms of action of the herbs (Table 1) and categorised them according to the known main mechanisms of action of Western medicines important in the treatment 


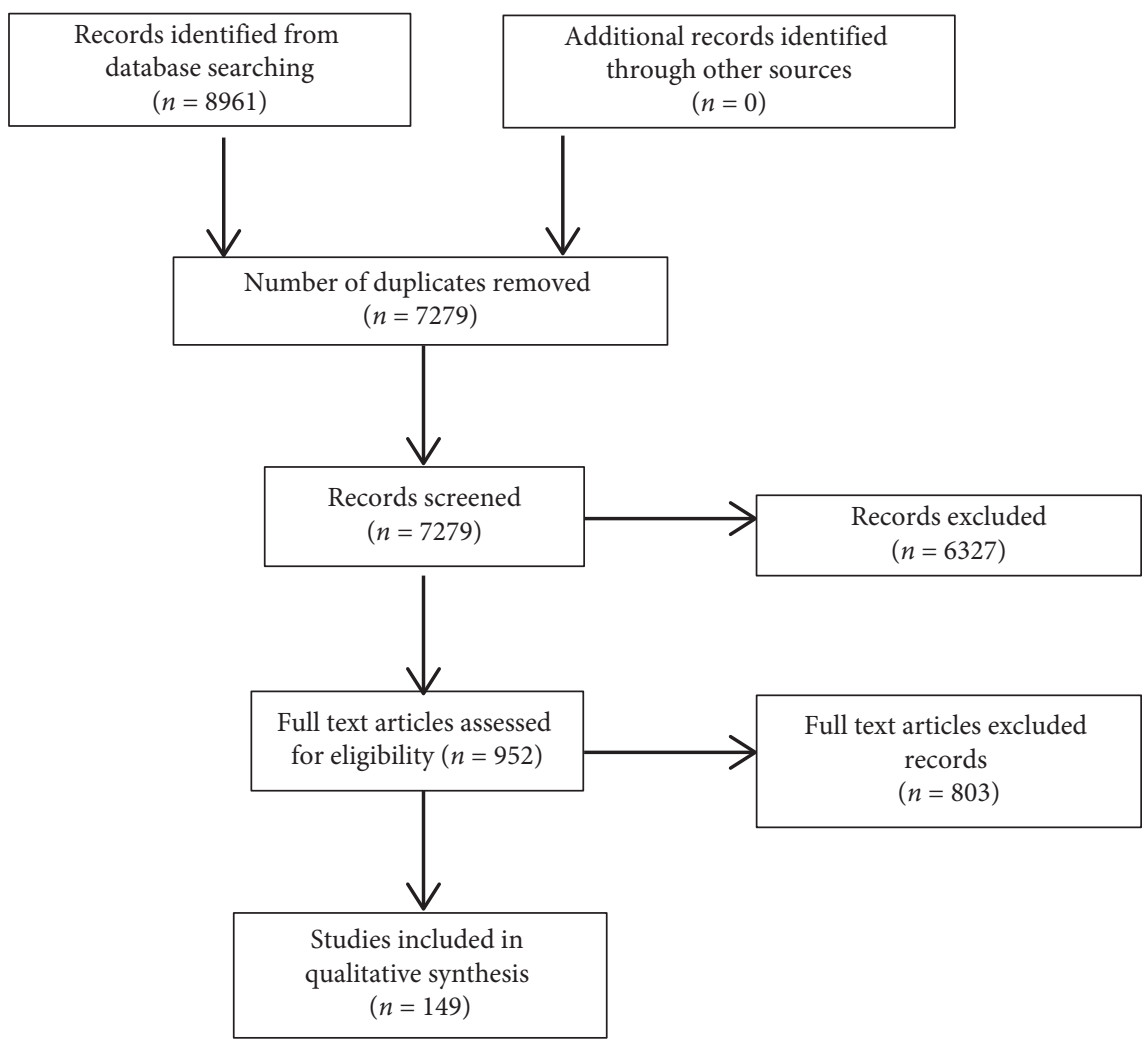

FIGURE 2: Study flow diagram for the identification of articles of commonly used herbs.

TABLE 1: Summary of MOA of herbs frequently used in asthma.

\begin{tabular}{|c|c|}
\hline Herb species & Mechanism of action \\
\hline Glycyrrhiza uralensis & $\begin{array}{l}\text { In murine models } \\
\text { (1) Bronchodilation } \\
\text { LPS-induced NO production } \\
\text { Attenuates acetylcholine- and carbachol-induced contractions } \\
\text { (2) Anti-inflammatory } \\
\text { Inhibit T lymphocytes, eosinophils, IgE, IL-13, and TNF-a } \\
\text { Upregulate caspase-3 and Bax } \\
\text { Steroid-like activities } \\
\text { Downregulate Bcl-2 } \\
\text { (3) Mucolytic } \\
\text { Inhibit MUC5AC gene expression, production and secretion via regulation of NF- } \kappa \mathrm{B}, \mathrm{STAT} 6 \text {, and HDAC2 } \\
\text { In guinea pig models } \\
\text { (1) Bronchodilation } \\
\text { Activate c-GMP and open calcium channels } \\
\text { Human airway epithelial cells } \\
\text { (1) Mucolytic } \\
\text { Inhibit PMA-induced MUC5AC mucin production } \\
\text { (2) Anti-inflammatory } \\
\text { Inhibit Th2-associated cytokines } \\
\text { Human peripheral blood mononuclear cells } \\
\text { (1) Anti-inflammatory } \\
\text { Phytohaemagglutinin-induced proliferation and inhibition of TNF-alpha, IFN-gamma, and IL-10 } \\
\text { production } \\
\text { In vitro } \\
\text { (1) Anti-inflammatory } \\
\text { Inhibit memory Th2 responses } \\
\text { Inhibit IL-4 and Eotaxin-1 secretion }\end{array}$ \\
\hline
\end{tabular}


TABLE 1: Continued.

\begin{tabular}{ll}
\hline Herb species & \multicolumn{1}{c}{ Mechanism of action } \\
\hline & In murine models \\
(1) Anti-inflammatory & Reduce recruitment of eosinophils, macrophages, and lymphocytes \\
Inhibit MAPK signalling and IL-4 activation & Activate IFN-y \\
\hline & In murine models \\
& (1) Anti-inflammatory \\
Pinellia ternata & Reduce recruitment of eosinophils \\
& Reduce IL-4 activation and IFN-y activation \\
\hline & In guinea pig models \\
& (1) Anti-inflammatory \\
Asarum sieboldii & Inhibit IL-4 activation and histamine release \\
& (2) Signalling pathway regulation \\
Regulate MMP-9 and TIMP-1 signalling
\end{tabular}

In murine models

(1) Anti-inflammatory

Inhibit IL-4, IL-5, IgE, and TNF- $\alpha$ activation

Inhibit eosinophil activation

Regulate Th1/Th2 balance

Inhibit NF-kB activation

Inhibit production of NO, PGE2, TNF-a, iNOS, and COX-2

Inhibit release of IL-1B and IL-6

Pheretima aspergillum (2) Mucolytic

Decrease collagen deposition

Decrease mucin glycogen expression

In guinea pig models

(1) Anti-inflammatory

Regulate IFN-y, IL-4, and LTB4 production

In human models

(1) Anti-inflammatory

Inhibit TGF-B1 and SMAD2

In vitro

(1) Anti-inflammatory

Suppress NO production

Inhibit production of PGE2, IL-6, IL-1B

Aster tataricus L. f.

Inhibit expression of iNOS and COX-2 by inhibition of NF-KB activation

(2) Signalling blockade

Prevent activation of MAPK signalling cascade via inhibition of phosphorylation of c-Jun N-terminal

kinases, extracellular signal-regulated kinases, and p38

(3) Bronchodilation

Activate of B2-adrenoceptors

In murine models

(1) Anti-inflammatory

Suppress TH2 cytokines (IL-4, IL-5, and IL-13)

Suppress IgE, histamine production

Fritillaria cirrhosa D. Don

Reduce eosinophilic accumulation

Increase IFN- $\gamma$ production

(2) Block signalling pathways

Inhibit ERK/MAPK signalling activation

(3) Downregulate NOTCH 2 expression

(4) Inhibit MMP-2, MMP-9, and TIMP-1

In murine models

Lepidium apetalum

(1) Anti-inflammatory

Reduce expression of type 2 cytokines

Inhibit differentiation and activation of Th2 cytokines 
TABle 1: Continued.

\begin{tabular}{|c|c|}
\hline Herb species & Mechanism of action \\
\hline $\begin{array}{l}\text { Pericarpium Citri } \\
\text { Reticulatae }\end{array}$ & $\begin{array}{l}\text { In murine models } \\
\text { (1) Anti-inflammatory } \\
\text { Suppress eosinophil production } \\
\text { In guinea pig models } \\
\text { (1) Anti-inflammatory } \\
\text { Downregulate expression of eosinophils and serum IgE, IL-4, and IL-5 levels } \\
\text { (2) Bronchodilation } \\
\text { Activation of B2-adrenoceptors }\end{array}$ \\
\hline Cortex Mori & $\begin{array}{l}\text { In murine models } \\
\text { (1) Anti-inflammatory } \\
\text { Enhancement of CD } 4(+) \mathrm{CD} 25(+) \text { Foxp } 3(+) \text { regulatory T cells and inhibition of Th2 cytokines such as } \\
\text { interleukin (IL) }-4,-5 \text { and }-13 \\
\text { (2) Anticholinergic }\end{array}$ \\
\hline Ephedra sinica Stapf & $\begin{array}{l}\text { In murine models } \\
\text { (1)Anti-inflammatory } \\
\text { Reduce infiltration of inflammatory cells in the lung } \\
\text { Regulate levels of inflammatory factors such as OVA-IgE, IL-4, and IL-13 and downregulate the expression } \\
\text { of p65 NF-k B protein } \\
\text { (2) Bronchodilator } \\
\text { Activate a-, B1-, and B2-adrenoceptors }\end{array}$ \\
\hline Zingiber officinale Roscoe & $\begin{array}{l}\text { In murine models } \\
\text { (1) Anti-inflammatory } \\
\text { Inhibit Th2-mediated immune response } \\
\text { (2) Bronchodilation } \\
\text { Reduce Ca2+ influx in smooth muscle and promote } \beta \text { agonist-induced relaxation in human airway smooth } \\
\text { muscle by suppressing phosphodiesterase 4D }\end{array}$ \\
\hline Tussilago farfara & $\begin{array}{l}\text { In murine models } \\
\text { (1) Anti-inflammatory } \\
\text { Regulate IgE, IL-4, and IL-13 levels } \\
\text { Downregulate the expression of p65 NF-kB protein } \\
\text { Inhibit NO, MAPKs, and NF-kB } \\
\text { Suppress expression of PGE2, TNF- } \alpha \text {, and HMGB1 } \\
\text { Reduce production of IL-4, IL-5, IL-13, and IL-17 } \\
\text { Reduce IgE in serum by regulating Th1/Th2 cells } \\
\text { Increase HO-1 levels affecting Nrf2/HO-1 pathway } \\
\text { (2) Mucolytic } \\
\text { Decrease mucin production by regulating NF-kB }\end{array}$ \\
\hline Platycodon grandifloras & $\begin{array}{l}\text { In murine models } \\
\text { Serum concentrations of NF- } \kappa \mathrm{B}, \mathrm{MMP}-9 \text {, and TIMP-1 decreased significantly } \\
\text { In guinea pig models } \\
\text { (1) Anti-inflammatory } \\
\text { Promote and regulate release of LXA4 } \\
\text { Reduce oxygen-free radicals } \\
\text { Promote secretion of IFN- } \gamma \\
\text { Regulate Th1/Th2 balance }\end{array}$ \\
\hline Fritillaria thunbergii & $\begin{array}{l}\text { In guinea pig models } \\
\text { Inhibit PDE and prevent inactivation of cAMP }\end{array}$ \\
\hline Paeonia lactiflora & $\begin{array}{l}\text { In murine models } \\
\text { (1) Anti-inflammatory } \\
\text { Inhibit IL-22 and IL-13 }\end{array}$ \\
\hline Magnolia officinalis & $\begin{array}{l}\text { In murine models } \\
\text { (1) Anti-inflammatory } \\
\text { Inhibit IL-4, IL-6, and IL-17 } \\
\text { Decrease serum MDA level } \\
\text { Increase SOD and GSH-Px/p-JNK, NF- } \kappa \mathrm{B} \text {, caspase-3, and } \gamma \mathrm{H} 2 \text { Ax levels } \\
\text { Inhibition of the PI3 K/Akt signalling pathway by TLR2 and TLR4 receptors-Steroid-like activities }\end{array}$ \\
\hline
\end{tabular}


TABLE 1: Continued.

\begin{tabular}{|c|c|}
\hline Herb species & Mechanism of action \\
\hline Bupleurum chinense & $\begin{array}{l}\text { In guinea pig models } \\
\text { (1) Anti-inflammatory } \\
\text { Reduce eosinophil levels } \\
\text { Reduce serum levels of IL- } 5 \text { and TNF- } \alpha\end{array}$ \\
\hline Scutellaria baicalensis & $\begin{array}{l}\text { In murine models } \\
\text { (1) Anti-inflammatory } \\
\text { Inhibit TGF- } \beta 1 \text { and } \alpha \text {-SMA, and decrease p-ERK1/2 } \\
\text { Inhibit phosphorylated p38 protein } \\
\text { Inhibit IgE, IL-4, IL-5, IL-6, IL-17A } \\
\text { Reduce STAT3 protein level } \\
\text { Promote expression of FOXP3 protein } \\
\text { Increase serum MDA levels } \\
\text { Promote expression of FOXP3 protein } \\
\text { Inhibit HMGB1 } \\
\text { Inhibit protein expression of } \alpha \text {-SMA and TLR4 } \\
\text { Expression of GATA-3 and STAT6 } \\
\text { Suppress Th2 response } \\
\text { Increase IL-10 levels }\end{array}$ \\
\hline Perilla frutescens & None found \\
\hline Anemarrhena Rhizoma & $\begin{array}{l}\text { In guinea pig models } \\
\text { Reduce serum NO, BALF, and ET-1 }\end{array}$ \\
\hline Gypsum fibrosum & None found \\
\hline Eriobotryae Folium & $\begin{array}{l}\text { In murine models } \\
\text { Reduce CD4+ } \\
\text { Increase CD } 8+ \\
\text { Regulate CD } 4+/ C D 8+\text { dysfunction }\end{array}$ \\
\hline Cinnamomi Ramulus & $\begin{array}{l}\text { In murine models } \\
\text { (1) Anti-inflammatory } \\
\text { Inhibition of eosinophils, IFN- } \gamma \text {, IL-4, IgE, histamine, and } \beta \text {-hexosaminidase release }\end{array}$ \\
\hline Zingiberis rhizoma & None found \\
\hline Schisandra Fructus & $\begin{array}{l}\text { In murine models } \\
\text { (1) Anti-inflammatory } \\
\text { Reduce EOS } \\
\text { Increase SOD in serum } \\
\text { Reduce MDA } \\
\text { Inhibit TNF- } \alpha \text {, IL- } 1 \beta \text {, and IL- } 6 \text { expression } \\
\text { Regulate the HMGB1/TLR4/NF- } \kappa \text { B signalling pathway }\end{array}$ \\
\hline
\end{tabular}

of asthma. Based on known mechanisms, the herbs were divided broadly into beta-adrenergic agonist, steroid-like, anticholinergics, PDE antagonist, leukotriene antagonist, and herbs with monoclonal effects or those affecting signalling pathways (Table 2 ). The schematic representation on how herbs act on the immunopathological pathways of asthma is depicted in Figure 3. The herbs act mainly on IL-4, IL-5, IL-13, and IL-17A and T cells on asthmatic pathways, which act to mobilize inflammatory cells, tissue repair, and remodelling, causing bronchial hyperreactivity and induction of chemokines.

\subsection{Proposed Guidelines in Relation to GINA Guidelines.} The proposed guidelines (Figure 4), based on existing GINA guidelines, describe a stepwise approach to treating asthma, where increments in medication are made if existing treatment is insufficient for controlling a patient's symptoms [95].
Step 1 involves using a low to moderate dose of beta-2adrenoreceptor agonist as required. Herbs which work similarly include Aster tataricus, Pericarpium Citri Reticulatae, Ephedra sinica Stapf, Zingiber officinale Roscoe, Tussilago farfara, and Scutellaria baicalensis.

Step 2 involves the addition of a low dose of corticosteroids. This can be achieved by adding Magnolia officinalis to the existing herbs or possibly by substituting them with Glycyrrhiza uralensis alone.

Step 3 involves increasing the dose of the beta-2adrenoreceptor agonist to a moderate-high dose and either using a medium dose of corticosteroid or adding a leukotriene receptor antagonist (LTRA) to the lowdose corticosteroid. Pheretima aspergillum is an LTRA and could potentially be useful.

Step 4 involves the addition of either an anticholinergic or an LTRA or increasing to a moderate dose of corticosteroid, whichever was not undertaken during step 
TABLe 2: Phenotype specific asthma therapeutic targeting of herbs.

\begin{tabular}{|c|c|c|c|}
\hline Chinese name & Latin name & MOA targeting asthmatic subgroups & Targeted asthmatic phenotype \\
\hline \multicolumn{4}{|c|}{$\beta$-Adrenergic agonist } \\
\hline Zi Wan & Aster tataricus L. f. & N/A & $\mathrm{N} / \mathrm{A}$ \\
\hline Chen Pi & $\begin{array}{l}\text { Pericarpium Citri } \\
\quad \text { Reticulatae }\end{array}$ & $\begin{array}{l}\text { (1) Inhibits IL-5 and reduction of eosinophil } \\
\text { (2) Inhibits IgE and IL-4 }\end{array}$ & $\begin{array}{l}\text { (1) Idiopathic eosinophilic } \\
\text { asthma } \\
\text { (2) Allergen exacerbated asthma }\end{array}$ \\
\hline Ma Huang & Ephedra sinica Stapf & Inhibits IL-4 and IL-13 & Allergen exacerbated asthma \\
\hline Sheng Jiang & Zingiber officinale Roscoe & N/A & $\mathrm{N} / \mathrm{A}$ \\
\hline $\begin{array}{l}\text { Kuan Dong } \\
\text { Hua }\end{array}$ & Tussilago farfara & $\begin{array}{l}\text { (1) Inhibits IL-4, IL-13, and IgE } \\
\text { (2) Inhibits IL-5 } \\
\text { (3) Inhibits IL-17 }\end{array}$ & $\begin{array}{l}\text { (1) Allergen exacerbated asthma } \\
\text { (2) Idiopathic eosinophilic } \\
\text { asthma } \\
\text { (3) Neutrophilic asthma }\end{array}$ \\
\hline Huang Qin & Scutellaria baicalensis & $\begin{array}{l}\text { (1) Inhibits IL-4, IL-13, and IgE } \\
\text { (2) Inhibits IL-5 } \\
\text { (3) Inhibits IL-17A }\end{array}$ & $\begin{array}{l}\text { (1) Allergen exacerbated asthma } \\
\text { (2) Idiopathic eosinophilic } \\
\text { asthma } \\
\text { (3) Neutrophilic asthma }\end{array}$ \\
\hline \multicolumn{4}{|l|}{ Steroidal effects } \\
\hline Hou Po & Magnolia officinalis & $\begin{array}{l}\text { (1) Inhibits IL-4 and IL-13 } \\
\text { (2) Inhibits IL-5 } \\
\text { (3) Inhibits IL-17A } \\
\text { (4) Inhibits leukotriene release }\end{array}$ & $\begin{array}{l}\text { (1) Allergen exacerbated asthma } \\
\text { (2) Idiopathic eosinophilic } \\
\text { asthma } \\
\text { (3) Neutrophilic asthma } \\
\text { (4) Aspirin induced asthma }\end{array}$ \\
\hline PDE inhibitor & & & \\
\hline $\begin{array}{l}\text { Zhe Bei } \\
\beta \text {-Adrenergic an }\end{array}$ & $\begin{array}{l}\text { Fritillaria thunbergii } \\
\text { eroidal effects }\end{array}$ & N/A & N/A \\
\hline Gan Cao & Glycyrrhiza uralensis & $\begin{array}{l}\text { (1) Inhibits IgE and IL-13 } \\
\text { (2) Steroidal effects and inhibits IL-5 antagonist } \\
\text { (3) Steroidal effects }\end{array}$ & $\begin{array}{l}\text { (1) Allergen exacerbated asthma } \\
\text { (2) Idiopathic eosinophilic } \\
\text { asthma } \\
\text { (3) Neutrophilic asthma }\end{array}$ \\
\hline \multicolumn{4}{|l|}{ Anticholinergic } \\
\hline Sang Bai Pi & Cortex Mori & $\begin{array}{l}\text { (1) Inhibits IL-4 and IL-13 } \\
\text { (2) Inhibits IL-5 }\end{array}$ & $\begin{array}{l}\text { (1) Allergen exacerbated asthma } \\
\text { (2) Idiopathic eosinophilic } \\
\text { asthma }\end{array}$ \\
\hline \multicolumn{4}{|c|}{ Leukotriene antagonist } \\
\hline Di Long & Pheretima aspergillum & $\begin{array}{l}\text { (1) Leukotriene antagonist } \\
\text { (2) Inhibits IgE and IL-4 } \\
\text { (3) Reduces eosinophils and inhibits IL-5 }\end{array}$ & $\begin{array}{l}\text { (1) Aspirin induced asthma } \\
\text { (2) Allergen exacerbated asthma } \\
\text { (3) Idiopathic eosinophilic } \\
\text { asthma }\end{array}$ \\
\hline \multicolumn{4}{|c|}{ Inhibition of IL-4 } \\
\hline Xi Xin & Asarum sieboldii & Inhibits IL-4 and histamine release & Allergen exacerbated asthma \\
\hline Ban Xia & Pinellia ternata & & Allergen exacerbated asthma \\
\hline Ku Xing Ren & Prunus armeniaca & Inhibits IL-4 & Allergen exacerbated asthma \\
\hline Inhibition of IL- & & & \\
\hline Wu Wei Zi & Schisandra Fructus & Inhibits IL-17 & Neutrophilic asthma \\
\hline \multicolumn{4}{|c|}{ Regulation of T helper cells } \\
\hline Ting Li Zi & Lepidium apetalum & $\begin{array}{l}\text { Reduces the expression of Th2 cytokines and } \\
\text { inhibits differentiation and activation of Th2 cells. }\end{array}$ & Allergen exacerbated asthma \\
\hline $\mathrm{Su} \mathrm{Zi}$ & Perilla frutescens & Suppression of allergen-specific Th2 response & Allergen exacerbated asthma \\
\hline $\mathrm{Pi} \mathrm{Pa} \mathrm{Ye}$ & Eriobotryae Folium & $\begin{array}{l}\text { Reduction of CD4+, rises CD 8+, and alters CD4+/ } \\
\qquad \mathrm{CD} 8+\text { dysfunction }\end{array}$ & Allergen exacerbated asthma \\
\hline \multicolumn{4}{|c|}{ Multiple monoclonal effects for asthma } \\
\hline Zhi Mu & Anemarrhena Rhizoma & $\begin{array}{l}\text { (1) Inhibits IL-5 and reduction of eosinophil } \\
\text { (2) Inhibits histamine release, IgE, IL-4, and IL-13 }\end{array}$ & $\begin{array}{l}\text { (1) Idiopathic eosinophilic } \\
\text { asthma } \\
\text { (2) Allergen exacerbated asthma }\end{array}$ \\
\hline Jie Geng & Platycodon grandifloras & $\begin{array}{l}\text { (1) Inhibits IL-4 and IL-13 } \\
\text { (2) Inhibits IL-5 } \\
\text { (3) Inhibits IL-17 }\end{array}$ & $\begin{array}{l}\text { (1) Allergen exacerbated asthma } \\
\text { (2) Idiopathic eosinophilic } \\
\text { asthma } \\
\text { (3) Neutrophilic asthma }\end{array}$ \\
\hline Shao Yao & Paeonia lactiflora & $\begin{array}{l}\text { (1) Inhibits IL-4 and IL-13 } \\
\text { (2) Inhibits IL-5 and reduces eosinophil } \\
\text { (3) Inhibits IL-17 and reduces neutrophil count }\end{array}$ & $\begin{array}{l}\text { (1) Allergen exacerbated asthma } \\
\text { (2) Idiopathic eosinophilic } \\
\text { asthma } \\
\text { (3) Neutrophilic asthma }\end{array}$ \\
\hline
\end{tabular}


TABLE 2: Continued.

\begin{tabular}{|c|c|c|c|}
\hline Chinese name & Latin name & MOA targeting asthmatic subgroups & Targeted asthmatic phenotype \\
\hline Chai $\mathrm{Hu}$ & Bupleurum chinense & $\begin{array}{l}\text { (1) Inhibits IL-4 and IgE } \\
\text { (2) Inhibits IL-5 } \\
\text { (3) Inhibits IL-17A }\end{array}$ & $\begin{array}{l}\text { (1) Allergen exacerbated asthma } \\
\text { (2) Idiopathic eosinophilic } \\
\text { asthma } \\
\text { (3) Neutrophilic asthma }\end{array}$ \\
\hline Gui Zi & Cinnamomi Ramulus & (1) Inhibits IgE and IL-4 & Allergen exacerbated asthma \\
\hline Alteration of & expression/signaling patl & & 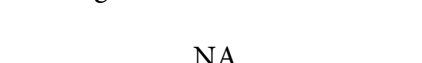 \\
\hline
\end{tabular}

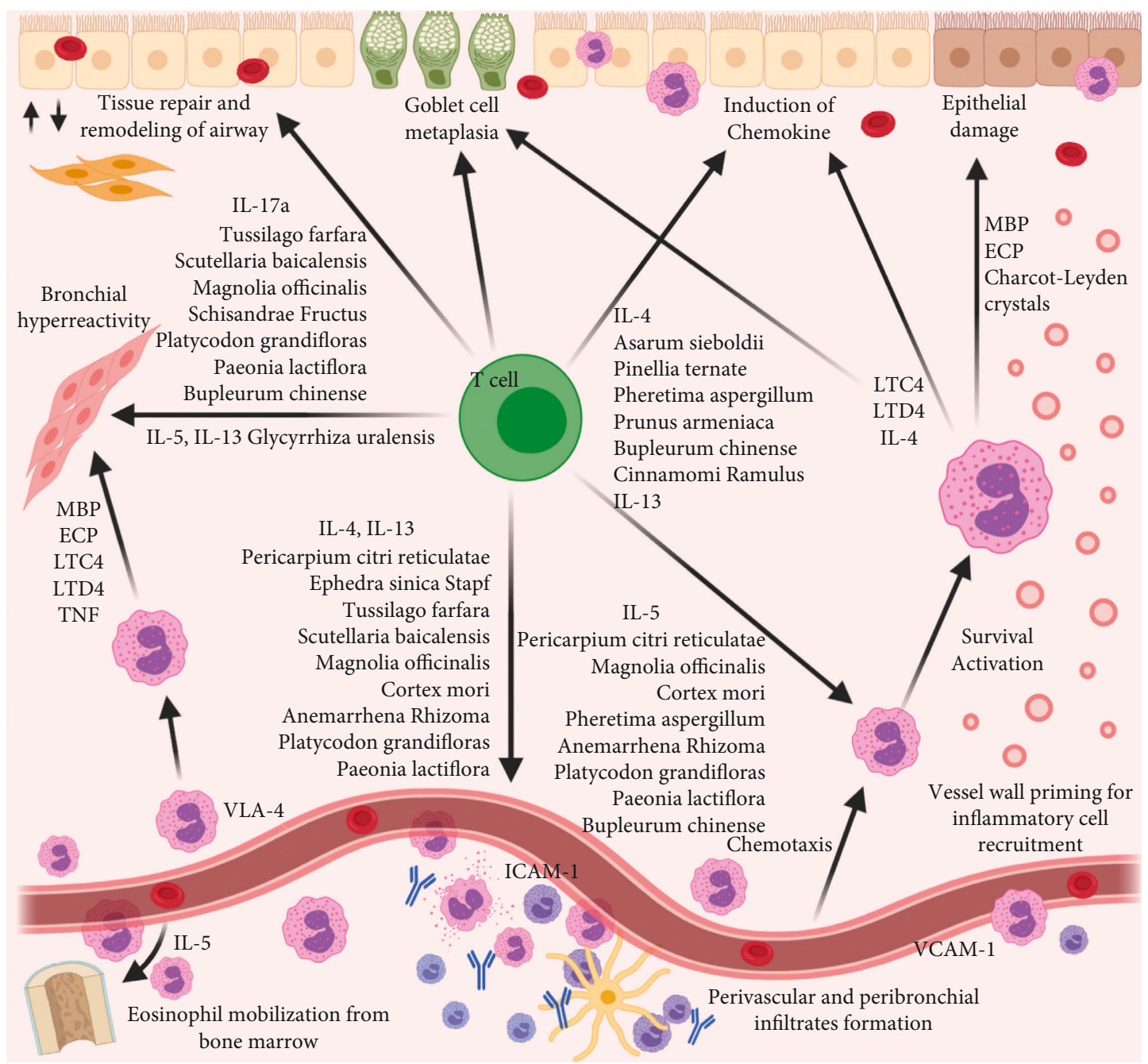

FIgURE 3: Chinese medicine targeted therapy on immunopathological pathways of asthma.

3. Cortex Mori has anticholinergic effects and could have potential use (Figure 4).

Step 5 involves switching to a high dose of corticosteroid and the addition of drugs with effects such as inhibiting IgE, IL-4, or IL-5, guided by the phenotypic assessment by an asthma specialist. Herbs that may be useful for these purposes include Asarum sieboldii, Pinellia ternata, and Prunus armeniaca which inhibit IL-4, Schisandra Fructus which inhibits IL-17, Lepidium apetalum and Perilla frutescens which regulate Th2 helper cell activity, or Anemarrhena Rhizoma,
Eriobotryae Folium, Platycodon grandifloras, Paeonia lactiflora, Bupleurum chinense, and Cinnamomi Ramulus which have a range of effects against multiple targets (Table 2).

3.5. Frequently Prescribed TCM Formulas in Asthma. A total of 16 formulas were identified as frequently prescribed for asthma (Table 3), of which 12 were "stand-alone formulas" which are usually prescribed independently and 4 were "add-on formulas" which are used in addition to "stand- 


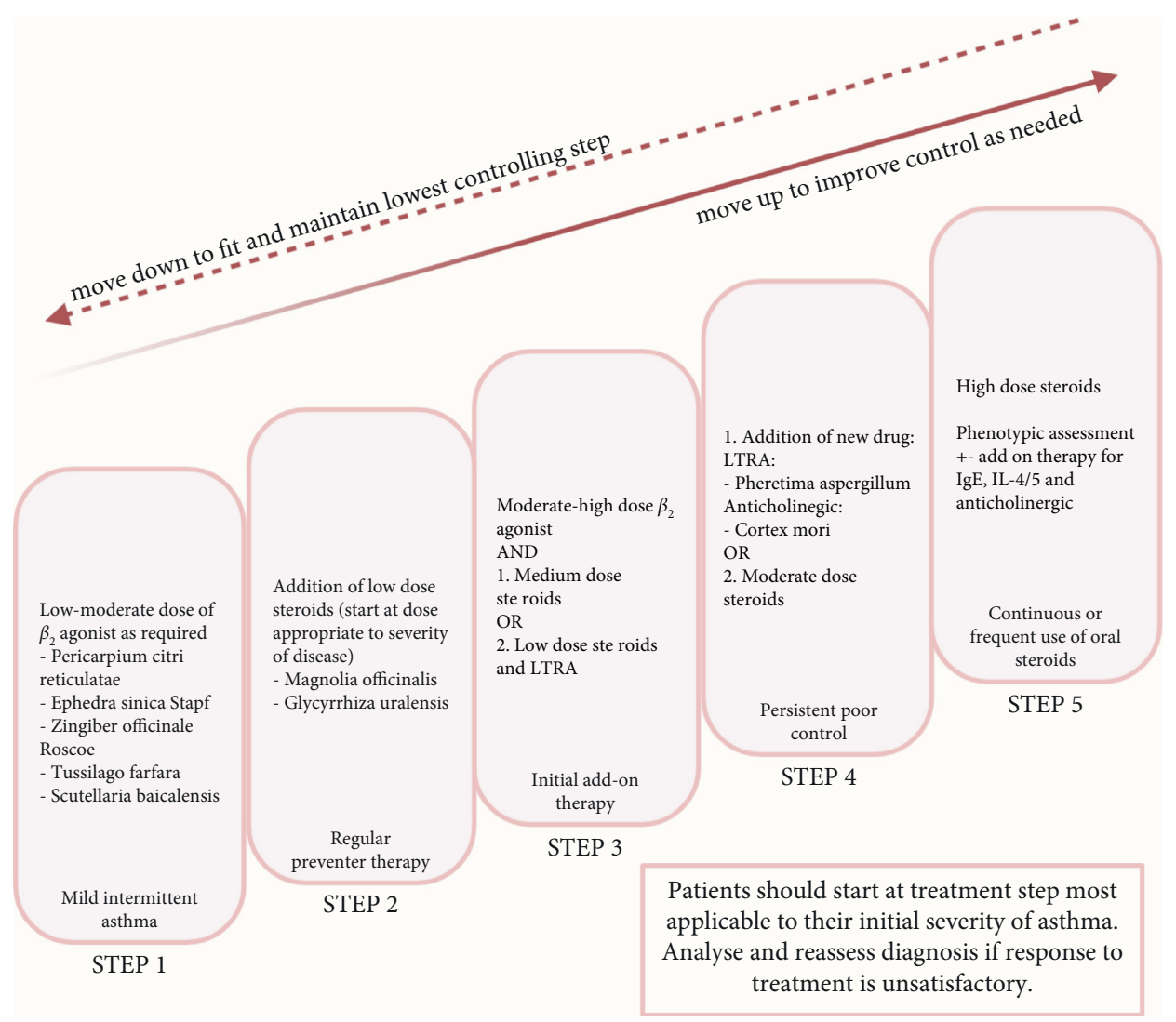

Figure 4: Proposed guideline for traditional Chinese medicine based on existing GINA.

alone formulas" during an acute exacerbation [96]. The MOA of the herbs identified in the formulas was analysed, which demonstrated that "stand-alone formulas" contain herbs with beta-agonist, steroid-like effects or leukotriene antagonist mechanisms, or a combination of beta-agonist and steroid-like effects/leukotriene antagonist. However, "add-on formulas" only had either steroid-like effects or regulated $\mathrm{T}$ helper cells.

\section{Discussion}

4.1. Mechanism of Action of Herbs and Concomitant Use of Drugs and Herbs. Despite theoretical differences between TCM and Western medicine, research is increasingly suggesting that herbal medicines have similar MOA to that of Western medicines (Table 1). The understanding of MOA allows characterisation of herbs in relation to Western medicines and improves prescription methods of TCM physicians. For example, TCM physicians will be able to select herbs with beta-agonist effects in patients presenting with acute asthma. It also allows minimisation of possible interactions between herbs and drugs if taken concurrently, and the use of readily available antidotes should occur. Recent research showed that up to $33.6 \%$ of patients in the United Kingdom consume both herbal and prescription medicine together [97]. This could result in overdose or interactions when herbs and drugs with similar MOA be consumed concurrently [98, 99]. Herbs such as Gypsum fibrosum and Zingiberis rhizoma which have no known
MOA should not be used concurrently with Western medicines to prevent the occurrence of any unknown side effects.

4.2. Standardization of TCM Management of Asthma. TCM physicians traditionally adopt a "Syndrome-Based" approach in diagnosing patients which is determined by the symptoms of the patient, looks of the tongue, and character of the pulse [100]. "Syndrome-Based" approach means that patients with the same diagnosis given by Western doctors might be diagnosed as different syndromes by TCM physicians, and as such, different management would be given. It is also a relatively subjective approach depending on the consulting physician(s) [101]. It would likely result in differences in outcomes for patients. Through the understanding of the underlying MOA of each herb used for asthma, a proposed guideline (Figure 4) can thus be formulated based on existing GINA guidelines [95]. This would ensure a standardized uniform outcome for patients regardless of "syndromes" characterized by TCM physicians and prevent herbs with repetitive or unknown MOA from being prescribed.

Unlike drugs, herbs are usually consumed orally, and their duration of effect has not been elicited. The proposed guideline takes into account the differences in the mode of administration and durations of the effect of herbs despite the similarity in MOA. Similar to existing GINA guidelines, prescription will be stepwise and incremental according to 
TABle 3: Analysis of MOA of commonly used TCM formulas.

\begin{tabular}{|c|c|c|c|c|}
\hline $\begin{array}{l}\text { Formula } \\
\text { (Chinese) }\end{array}$ & Formulas & Key ingredients & Main MOA & $\begin{array}{l}\text { Individual/Add- } \\
\text { on formula }\end{array}$ \\
\hline 三子养亲汤 & $\begin{array}{c}\text { San Zi Yang Qin } \\
\text { Tang }\end{array}$ & Perilla frutescens & Regulation of Th2 cell & Add-on \\
\hline 三子汤 & San $\mathrm{Zi}$ Tang & Lepidium apetalum and Perilla frutescens & Regulation of Th2 cell & Add-on \\
\hline 半夏厚朴汤 & $\begin{array}{c}\text { Ban Xia Hou Po } \\
\text { Tang }\end{array}$ & Pinellia ternata and Magnolia officinalis & Steroid-like effects & Add-on \\
\hline $\begin{array}{l}\text { 桂枝加厚朴 } \\
\text { 杏仁汤 }\end{array}$ & $\begin{array}{l}\text { Gui Zhi Jia Hou Po } \\
\text { Xing Ren Tang }\end{array}$ & $\begin{array}{c}\text { Cinnamomi Ramulus, Magnolia officinalis, Prunus } \\
\text { armeniaca, and Glycyrrhiza uralensis }\end{array}$ & Steroid-like effects & Add-on \\
\hline 射干麻黄汤 & $\begin{array}{l}\text { She Gan Ma Huang } \\
\text { Tang }\end{array}$ & $\begin{array}{l}\text { Ephedra sinica Stapf, Aster tataricus L. f., Pinellia ternata, } \\
\text { Schisandra Fructus, Asarum sieboldii, and Tussilago farfara }\end{array}$ & $\beta$-Agonist & Individual \\
\hline 康连智方 & $\begin{array}{l}\text { Kang Lian Zhi } \\
\text { Fang }\end{array}$ & $\begin{array}{c}\text { Ephedra sinica Stapf, Pinellia ternata, Asarum sieboldii, and } \\
\text { Schisandra fructus }\end{array}$ & $\beta$-Agonist & Individual \\
\hline $\begin{array}{l}\text { 董氏治喘基 } \\
\text { 本方 }\end{array}$ & $\begin{array}{l}\text { Dong Shi Zhi } \\
\text { Chuan Ji Ben Fang }\end{array}$ & $\begin{array}{c}\text { Ephedra sinica Stapf, Prunus armeniaca, and Pheretima } \\
\text { aspergillum }\end{array}$ & $\begin{array}{l}\beta \text {-Agonist and } \\
\text { leukotriene } \\
\text { antagonist }\end{array}$ & Individual \\
\hline 麻杏石甘汤 & $\begin{array}{l}\text { Ma Xing Shi Gan } \\
\text { Tang }\end{array}$ & $\begin{array}{c}\text { Ephedra sinica Stapf, Glycyrrhiza uralensis, and Prunus } \\
\text { armeniaca }\end{array}$ & $\begin{array}{l}\beta \text {-Agonist and } \\
\text { steroid-like effects }\end{array}$ & Individual \\
\hline 三拗汤 & San Ao Tang & $\begin{array}{c}\text { Ephedra sinica Stapf, Glycyrrhiza uralensis, and Prunus } \\
\text { armeniaca }\end{array}$ & $\begin{array}{l}\beta \text {-Agonist and } \\
\text { steroid-like effects }\end{array}$ & Individual \\
\hline $\begin{array}{l}\text { 茯苓杏仁甘 } \\
\text { 草汤 }\end{array}$ & $\begin{array}{l}\text { Fu Ling Xing Ren } \\
\text { Gan Cao Tang }\end{array}$ & Prunus armeniaca and Glycyrrhiza uralensis & $\begin{array}{l}\beta \text {-Agonist and } \\
\text { steroid-like effects }\end{array}$ & Individual \\
\hline 六君子汤 & Liu Jun Zi Tang & $\begin{array}{c}\text { Glycyrrhiza uralensis, Pinellia ternata, and Pericarpium } \\
\text { Citri Reticulatae }\end{array}$ & $\begin{array}{l}\beta \text {-Agonist and } \\
\text { steroid-like effects }\end{array}$ & Individual \\
\hline 治喘方 & Zhi Chuan Fang & $\begin{array}{l}\text { Ephedra sinica Stapf, Asarum sieboldii, Glycyrrhiza } \\
\text { uralensis, Schisandra Fructus, and Pinellia ternata }\end{array}$ & $\begin{array}{l}\beta \text {-Agonist and } \\
\text { steroid-like effects }\end{array}$ & Individual \\
\hline 苓桂术甘汤 & $\begin{array}{l}\text { Ling Gui Shu Gan } \\
\text { Tang }\end{array}$ & Cinnamomi Ramulus and Glycyrrhiza uralensis & $\begin{array}{c}\beta \text {-Agonist and } \\
\text { steroid-like effects }\end{array}$ & Individual \\
\hline 小柴胡汤 & Xiao Chai Hu Tang & $\begin{array}{c}\text { Bupleurum chinense, Scutellaria baicalensis, Pinellia } \\
\text { ternata, and Glycyrrhiza uralensis }\end{array}$ & $\begin{array}{l}\beta \text {-Agonist and } \\
\text { steroid-like effects }\end{array}$ & Individual \\
\hline 小青龙汤 & $\begin{array}{l}\text { Xiao Qing Long } \\
\text { Tang }\end{array}$ & $\begin{array}{c}\text { Ephedra sinica Stapf, Paeonia lactiflora, Asarum sieboldii, } \\
\text { Glycyrrhiza uralensis, Cinnamomi Ramulus, Schisandra } \\
\text { Fructus, and Pinellia ternata }\end{array}$ & $\begin{array}{l}\beta \text {-Agonist and } \\
\text { steroid-like effects }\end{array}$ & Individual \\
\hline 芶药甘草汤 & $\begin{array}{l}\text { Shao Yao Gan Cao } \\
\text { Tang }\end{array}$ & Paeonia lactiflora and Glycyrrhiza uralensis & $\begin{array}{l}\beta \text {-Agonist and } \\
\text { steroid-like effects }\end{array}$ & Individual \\
\hline
\end{tabular}

the severity of their asthma, from step 1 to 5. Worsening of symptoms warrants moving up the ladder, and dose reductions can be made if symptoms improve. This will ensure adequate herbs with appropriate MOA and dosage are prescribed.

4.3. Phenotype Specific Asthma Therapeutic Targeting of Herbs. In addition to the standard therapeutic MOA for asthma, herbs also seem to regulate the activity of inflammatory cells and cytokines by acting on particular pathways in the immunopathology of asthma (Figure 3). This aids not only in understanding of the way herbs work but can also be used to target a particular phenotype of asthma, e.g., downregulation of IgE in allergen-induced asthma. Biologics such as omalizumab, which targets specific cytokines, have long been employed in the management of asthma. Herbs with similar effects could potentially be employed in a similar fashion as biologics.

The therapeutic interventions for different phenotypes include IL-17 antagonist (neutrophilic asthma), IL-4/13 antagonist and anti-IgE (allergen-induced asthma), corticosteroids and IL-5 antagonist (idiopathic eosinophilic asthma), and leukotriene antagonist (aspirin exacerbated asthma) [102].

Herbs which target certain phenotypes through their effect on cytokines (Table 2) should be added after standardized therapy has been given and phenotypic assessment has been conducted, in line with GINA guidelines. This serves as an individualised management for patients with different asthmatic phenotypes and will lead to improved treatment outcomes.

4.4. Analysis of TCM Formulas Used for Asthma. Herbs are typically prescribed in various combinations as "TCM formulas," rather than individually. They can be broadly divided into "Stand-alone formulas" which can be used independently for diseases and "Add-on Formulas" which are usually added as adjuvants to "Stand-alone formulas" to enhance their therapeutic effects (Table 3). Interestingly, the analysis of "Stand-alone Formulas" has shown that despite the differences in herbs used, formulas generally consist of herbs with $\beta$-agonist and steroid-like effects as recommended by GINA guidelines [95]. On the other hand, "Addon Formulas" consist of herbs with steroid-like effects or 
assist in the regulation of $\mathrm{T}$ helper cells. However, none of the formulas have proceeded beyond step 3 of the GINA guidelines which could involve the addition of anticholinergics or leukotriene antagonists.

In addition, some formulas consist of several herbs with the same MOA, e.g., Ma Xing Shi Gan Tang which comprises of Ephedra sinica Stapf and Glycyrrhiza uralensis, both of which exerts the $\beta$-agonistic effect and Gui Zhi Jia Hou Po Xing Ren Tang which is made up of Magnolia officinalis and Glycyrrhiza uralensis, both of which exert steroid-like effects. Unknowingly, Ma Xing Shi Gan Tang could result in arrhythmias as a result of excessive $\beta$-adrenergic activity, while Gui Zhi Jia Hou Po Xing Ren Tang could result in iatrogenicinduced Cushing syndrome, one of the well documented side effects of steroids especially in systemic steroids administration [103]. Gui Zhi Jia Hou Po Xing Ren Tang should therefore be avoided and let alone as an "Add-on Formula;" as the "Stand-alone Formula," it is added onto and might already consist of steroidal elements. In addition, one of the existing formulas (Dong Shi Zhi Chuan Ji Ben Fang) also proceeded to include herbs with leukotriene antagonist activity without first including herbs with steroidlike effects as per GINA guidelines. This will likely result in the suboptimal management of patients with asthma.

\section{Conclusion}

With a rising number of patients seeking TCM [104], it is paramount for TCM physicians to understand the underlying MOA of herbs. This will allow the standardization of prescribing and result in a more guideline-based approach. In line with this approach, herbs with repetitive or unknown MOA should be avoided to reduce the risk of side effects. Both TCM physicians and doctors should also be wary of possible herb-drug interactions. A guideline-based approach will also allow greater continuity of care should a patient wish to transfer between TCM and Western medicine and prevent under or overmedication. However, patients should still seek the advice of their doctors prior to stopping medications.

Further research on Gypsum fibrosum and Zingiberis rhizoma to identify their underlying MOA is recommended.

\section{Data Availability}

The data used to support the findings of this study are available online.

\section{Disclosure}

Wong L. H. and Tay L. are the co-first authors.

\section{Conflicts of Interest}

The authors declare that there are no conflicts of interest.

\section{References}

[1] S. Hori, I. Mihaylov, J. C. Vasconcelos et al., "Patterns of complementary and alternative medicine use amongst outpatients in Tokyo, Japan," BMC Complementary and Alternative Medicine, vol. 8, p. 14, 2008.

[2] World Health Organization, WHO Global Report on Traditional and Complementary Medicine 2019, World Health Organization, Geneva, Switzerland, 2019, https://apps.who.int/iris/handle/ 10665/312342.20License:20CC20BY-NC-SA203.020IGO.

[3] M.-H. Lin, H.-T. Chang, C.-Y. Tu, T.-J. Chen, and S.-J. Hwang, "Prevalence of polyherbacy in ambulatory visits to traditional Chinese medicine clinics in Taiwan," International Journal of Environmental Research and Public Health, vol. 12, no. 8, pp. 9639-9657, 2015.

[4] A. A. Izzo, "Interactions between herbs and conventional drugs: overview of the clinical data," Medical Principles and Practice, vol. 21, no. 5, pp. 404-428, 2012.

[5] L. Yan, L. Rui, O. Zibo et al., "Herb network analysis for a famous TCM doctor's prescriptions on treatment of rheumatoid arthritis," Evidence-Based Complementary and Alternative Medicine, vol. 2015, Article ID 451319, 9 pages, 2015.

[6] H. H. Ching, M. L. Chun, and T. C. Tung, "Efficacy and safety of modified mai-men-dong-tang for treatment of allergic asthma," Pediatric Allergy and Immunology, vol. 16, no. 1, pp. 76-81, 2005.

[7] X. H. Lv, T. Wu, and D. Y. Qin, "Effect of glycyrrhizin on nitric oxide and nitric oxide synthase in mice model of pronchial asthma," Lishizhen Medicine and Materia Medica Research, vol. 20, no. 1, pp. 40-41, 2009.

[8] X. H. Lv, T. Wu, and D. Y. Qin, "The effect of glycyrrhizin on airway inflammation and PLA2 activity in mice asthmatic model," Lishizhen Medicine and Materia Medica Research, vol. 18, no. 10, pp. 2379-2380, 2007.

[9] W. Y. Zhang, Y. C. Gu, Y. Tang et al., "Effects of glycyrrhizic acid on ERK1/2 and p38 MAPK signaling pathway in a murine model of asthma," National Medical Journal of China, vol. 98, no. 16, pp. 1273-1278, 2018.

[10] Q. Z. Wu, Y. Tang, J. F. Zhang et al., "Therapeutic effects of glycyrrhizic acid on asthma airway inflammation in mice and its mechanism," National Medical Journal of China, vol. 94, no. 42, pp. 3338-3344, 2014.

[11] X. H. Lv, T. Wu, and D. Y. Qin, "Effect of liquorice on airway inflammation and TH1/TH2 imbalance in mouse model," Chinese Journal of Clinical Pharmacology and Therapeutics, vol. 11, no. 5, pp. 532-534, 2006.

[12] W. Chen, L. Ma, and L. S. Yang, "Effects of glycyrrhetinic acid on oxidative stress and NF- $\kappa \mathrm{B}$ signal path-way in bronchial asthma rats," Journal of Zhengzhou University (Medical Sciences), vol. 51, no. 6, pp. 762-765, 2016.

[13] H. X. Lin, K. Q. Feng, S. G. Zheng et al., "Effects of glycyrrhetinic acid on white blood cell count of alveolar lavage fluid and serum related inflammatory factors in asthmatic rats," Chinese Journal of Gerontology, vol. 36, no. 11, pp. 2613-2614, 2016.

[14] W. Chen, L. Ma, and L. S. Yang, "Effects of glycyrrhetinic acid on airway remodeling, Caspase $3, \mathrm{Bax}$ and Bcl-2 of lung tissue in bronchial asthma rats," Pharmacology and Clinics of Chinese Materia Medica, vol. 32, no. 4, pp. 16-19, 2016.

[15] B. Liu, Q. S. Wen, R. J. Zhang et al., "Antiasthmatic effect of isoliquiritigenin and its mechanism," Chinese Journal of Clinical Pharmacy, vol. 16, no. 6, pp. 348-352, 2007.

[16] W.-C. Huang, C.-Y. Liu, S.-C. Shen et al., "Protective effects of licochalcone A improve airway hyper-responsiveness and oxidative stress in a mouse model of asthma," Cells, vol. 8, no. 6, p. 617, 2019. 
[17] S. Fouladi, M. Masjedi, M. Ganjalikhani Hakemi, and N. Eskandari, "The review of in vitro and in vivo studies over the glycyrrhizic acid as natural remedy option for treatment of allergic asthma," Iranian Journal of Allergy, Asthma, and Immunology, vol. 18, no. 1, pp. 1-11, 2019.

[18] H. Hosseinzadeh and M. Nassiri-Asl, "Pharmacological effects of Glycyrrhiza spp. and its bioactive constituents: update and review," Phytotherapy Research, vol. 29, pp. 1868-1886, 2015.

[19] A. G. Stewart, "Airway wall remodelling and hyperresponsiveness: modelling remodelling in vitro and in vivo," Pulmonary Pharmacology \& Therapeutics, vol. 14, no. 3, pp. 255-265, 2001.

[20] C. Liu, D. Weir, P. Busse et al., "The flavonoid 7,4'-dihydroxyflavone inhibits MUC5AC gene expression, production, and secretion via regulation of NF- $\kappa \mathrm{B}$, STAT6, and HDAC2," Phytotherapy Research, vol. 29, no. 6, p. 925, 2015.

[21] N. Yang, S. Patil, J. Zhuge et al., "Glycyrrhiza uralensisFlavonoids present in anti-asthma formula, ASHMITM, inhibit memory Th2 responsesin vitroandin vivo," Phytotherapy Research, vol. 27, no. 9, pp. 1381-1391, 2013 Sep.

[22] C. Liu, N. Yang, B. Liang, R. Wang, Y. Song, and X. Li, "Constituents isolated from Glycyrrhiza uralensis inhibit IL4 and Eotaxin secretion in vitro," Journal of Allergy and Clinical Immunology, vol. 127, no. 2, p. AB262, 2011.

[23] B. Jayaprakasam, S. Doddaga, R. Wang, D. Holmes, J. Goldfarb, and X.-M. Li, "Licorice flavonoids inhibit eotaxin-1 secretion by human fetal lung fibroblastsin vitro," Journal of Agricultural and Food Chemistry, vol. 57, no. 3, pp. 820-825, 2009.

[24] G. G. L. Yue, B. C. L. Chan, H.-F. Kwok et al., "Screening for anti-inflammatory and bronchorelaxant activities of 12 commonly used Chinese herbal medicines," Phytotherapy Research, vol. 26, no. 6, pp. 915-925, 2012.

[25] H. Wei, D. Xu, D. F. Yao et al., "Effect of amygdalin on airway inflammation in mice with allergic asthma," Shaanxi Journal of Traditional Chinese Medicine, vol. 37, no. 12, pp. 1691-1693, 2016.

[26] L. S. Shan, "Amygdalin inhibits inflammation in mice with allergic asthma by regulating MAPK signalling pathway [A]. Chinese association of integrative medicine. Compilation of the 23rd national pediatric academic conference on integrated traditional Chinese and western medicine [C]," Chinese Association of Integrative Medicine, vol. 1, 2019.

[27] C. Huang, W. Peng, D. N. Wei et al., "Effect of pinelliae rhizoma praeparatum cum alumine polysaccharides on MUC5AC mRNA in lung tissues of allergic asthma model rats," Chinese Journal of Experimental Traditional Medical Formulae, vol. 25, no. 22, pp. 15-21, 2019.

[28] H. Chen, Y. Cheng, L. Y. Yang et al., "Experimental study of Asarum on small airway remodeling in asthmatic Guinea pigs," Journal of Sichuan Traditional Chinese Medicine, vol. 36, no. 06, pp. 66-68, 2018.

[29] H.-C. Chang, C.-C. Gong, C.-L. Chan, and O.-T. Mak, “A nebulized complex traditional Chinese medicine inhibits Histamine and IL-4 production by ovalbumin in Guinea pigs and can stabilize mast cells in vitro," BMC Complementary and Alternative Medicine, vol. 13, no. 1, p. 174, 2013.

[30] Q. F. Tang, S. H. Liu, X. P. Xu, and S. W. Song, "Effect of earthworm on airway remodeling in the murine model of chronic allergen-induced asthma," Journal of Guangdong Pharmaceutical University, vol. 29, no. 05, pp. 547-551, 2013.

[31] W. W. Lu, G. L. Wu, and G. Y. Yu, "Preliminary study on the mechanism of Chinese medicine in treating bronchial asthma," Zhejiang Journal of Traditional Chinese Medicine, vol. 52, no. 04, p. 299, 2017.

[32] H. C. Li, R. 'E. Xu, Y. N. Yang, and L. Wang, "Effects of earthworm injection on expression of TGF- $\beta 1 / \mathrm{smad} 2$ in bronchial epithelial cells allergized by house dust mite allergen dermatophagoides pteronyssinus antigens," Chinese Pharmaceutical Journal, vol. 45, no. 15, pp. 1145-1149, 2010.

[33] L. Wang, Y. Liu, F. Wang et al., "Inhibitory effect of ground dragon on the expression of $\alpha \mathrm{SMA}$ and FN in the lung tissue of mouse with asthma," Chinese Journal of Pathophysiology, vol. 25, no. 10, pp. 1964-1968, 2009.

[34] M. M. Zhou, X. P. Chu, H. Z. Yang et al., “Anti-inflammatory and anti-allergic effects of acidic fraction of Pheratima extract in asthma mice induced by ovalbumin," China Journal of Chinese Materia Medica, vol. 19, pp. 2249-2252, 2008.

[35] Q. Shi, X. Wang, J. Liu et al., "Anti-asthma effect of an active components group from decoction of Pheretima aspergillum and its chemical composition characterized by liquid chromatography-quadrupole time of flight mass spectrometry," Iran Journal of Pharmaceutical Research, vol. 18, no. 2, pp. 867-876, 2019.

[36] C. Huang, W. Li, Q. Zhang et al., "Anti-inflammatory activities of Guang-Pheretima extract in lipopolysaccharidestimulated RAW 264.7 murine macrophages," BMC Complementary and Alternative Medicine, vol. 18, no. 1, p. 46, 2018.

[37] C.-q. Huang, W. Li, B. Wu et al., "Pheretima aspergillum decoction suppresses inflammation and relieves asthma in a mouse model of bronchial asthma by NF- $\kappa \mathrm{B}$ inhibition," Journal of Ethnopharmacology, vol. 189, pp. 22-30, 2016.

[38] X. D. Su, H.-J. Jang, H. X. Li, Y. H. Kim, and S. Y. Yang, "Identification of potential inflammatory inhibitors from Aster tataricus," Bioorganic Chemistry, vol. 92, Article ID 103208, 2019.

[39] L. S. Chen and D. S. Zheng, "Bioactive constituents from the rhizomes of aster tataricus L. F. Afford the treatment of asthma through activation of beta(2)AR and inhibition of NFkappa b," Latin American Journal of Pharmacy, vol. 34, no. 2, pp. 291-295, 2015.

[40] Y. Wang, D. P. Feng, L. B. Sun et al., "Effect of fritillariae cirrhosae bulbus on Notch2 and inflammatory response in asthmatic mice," Progress of Anatomical Sciences, vol. 25, no. 05, pp. 583-585+589, 2019.

[41] Y. F. Zhang, H. N. Xu, W. Huang et al., "Effects of fritillariae cirrhosae bulbus on airway inflammation and ERK/MAPK signal pathway in asthma model mice," China Pharmacy, vol. 29 , no. 03 , pp. 343-348, 2018.

[42] H. Z. Li, Z. Y. Gao, W. Huang et al., "Effects of fritillariae cirrhosae bulbus on MMP-2, MMP-9 and TIMP-1 in murine asthma model," China Journal of Chinese Materia Medica, vol. 42, no. 21, pp. 4180-4186, 2017.

[43] H.-S. Yeum, Y.-C. Lee, S.-H. Kim, S.-S. Roh, J.-C. Lee, and Y.-B. Seo, "Fritillaria cirrhosa, Anemarrhena asphodeloides, Lee-Mo-Tang and cyclosporine a inhibit ovalbumin-induced eosinophil accumulation and Th2-mediated bronchial hyperresponsiveness in a murine model of asthma," Basic \& Clinical Pharmacology \& Toxicology, vol. 100, no. 3, pp. 205-213, 2007.

[44] S.-B. Kim, Y.-S. Seo, H. S. Kim et al., "Anti-asthmatic effects of lepidii seu Descurainiae Semen plant species in ovalbumin-induced asthmatic mice," Journal of Ethnopharmacology, vol. 244, Article ID 112083, 2019.

[45] Z. Q. Cai, Y. Dai, H. Y. Yuan et al., "Experimental study on pharmacodynamics of volatile oil of chenpi," China Pharmaceuticals, vol. 13, pp. 29-30, 2006. 
[46] M. Fu, B. Zou, K. An et al., "Anti-asthmatic activity of alkaloid compounds from Pericarpium citri reticulatae (citrus reticulata'Chachi')," Food \& Function, vol. 10, no. 2, pp. 903-911, 2019.

[47] Q. Shi, Z. Liu, Y. Yang et al., "Identification of anti-asthmatic compounds in Pericarpium citri reticulatae and evaluation of their synergistic effects," Acta Pharmacologica Sinica, vol. 30, no. 5, pp. 567-575, 2009.

[48] Z. Y. Duo, A. J. Wang, and Q. Li, "Effect of crude and honeyed mori cortex on serum NO, LPO, IL- 4 and IFN- $\gamma$ in asthmatic rats," Chinese Journal of Experimental Traditional Medical Formulae, vol. 21, no. 07, pp. 95-98, 2015.

[49] X. Z. Qin, L. C. Li, G. H. Yan, and G. Z. Li, "Effects of water extract of Cortex Mori to inflammatory cells of bronchoalveolar lavage fluid on model of asthma in mice," Journal of Medical Science Yanbian University, vol. 34, no. 2, pp. 93-95, 2011.

[50] Y. Y. Wei, F. Xu, X. W. Chen et al., "Antiasthmatic effects of the flavonoid of cortex mori," Lishizhen Medicine and Materia Medica Research, vol. 20, no. 11, pp. 2743-2745, 2009.

[51] F. Ma, D. J. Liao, Y. Lei et al., "Effect and mechanism of PDE4 inhibitor moracin $\mathrm{M}$ extracted from cortex mori radicis in mice with asthma," International Journal of Respiration, vol. 38, no. 7, pp. 485-489, 2018.

[52] H.-J. Kim, H. J. Lee, S.-J. Jeong, H.-J. Lee, S.-H. Kim, and E.-J. Park, "Cortex Mori Radicis extract exerts antiasthmatic effects via enhancement of CD4+CD25+Foxp3+ regulatory T cells and inhibition of Th2 cytokines in a mouse asthma model," Journal of Ethnopharmacology, vol. 138, no. 1, pp. 40-46, 2011.

[53] L. Huang, Y. N. Wang, and S. Y. Wu, "Research progress of pharmacological effects of traditional Chinese medicines ephedrae," China \& Foreign Medical Treatment, vol. 37, no. 7, pp. 195-198, 2018.

[54] H. Y. Li, Effects of Ephedrine Isomers and Cholic Acid Analogs, Used Alone or in Combination, against Histamine Induced Constriction of Guinea Pig Tracheal in Vitro, Academy of Military Sciences PLA China, Beijing, China, 2008.

[55] Z. Y. Li, J. Deng, B. Xiong et al., "Effect of ephedrine on expression of eotaxin in human bronchial epithelial cells stimulated by tumor necrosis factor- $\alpha$," Chongqing Medicine, vol. 45, no. 8, pp. 1016-1018, 2016.

[56] J. H. Xu, H. R. Cao, and Y. X. Chen, "Effect of herba ephedrae or honey-fried herba ephedrae alone on airway inflammation of asthmatic rats," Journal of New Chinese Medicine, vol. 46, no. 12, pp. 197-199, 2014.

[57] Q.-Q. Mao, X.-Y. Xu, S.-Y. Cao et al., "Bioactive compounds and bioactivities of ginger (zingiber officinale roscoe)," Foods, vol. 8, no. 6, p. 185, 2019.

[58] Y. H. Duan, The Effects and Mechanism of Total Sesquiterpenes from Tussilago Farfara L. on Ova-Sensitized Asthma Model in Rats, Shan Xi University, Taiyuan, China, 2019.

[59] B.-S. Choi, Y.-j. Kim, Y. P. Yoon, H. J. Lee, and C. J. Lee, "Tussilagone suppressed the production and gene expression of MUC5AC mucin via regulating nuclear factor-kappa B signaling pathway in airway epithelial cells," The Korean Journal of Physiology \& Pharmacology, vol. 22, no. 6, pp. 671-677, 2018.

[60] Y. Kim, M. Yeo, B. Oh et al., "Tussilagone inhibits the inflammatory response and improves survival in CLP-Induced septic mice," International Journal of Molecular Sciences, vol. 18, no. 12, p. 2744, 2017.
[61] J. Li, W. Gao, J. Gao et al., "Metabolomics reveal the protective effect of Farfarae Flos against asthma using an OVAinduced rat model," RSC Advances, vol. 7, no. 63, pp. 39929-39939, 2017.

[62] L. Wang, W. N. Du, S. T. Guo et al., "Effects of Platycodon grandiflorum on bronchial remodeling in asthmatic rats," Chinese Journal of School Doctor, vol. 32, no. 11, pp. 854-856, 2018.

[63] W. Y. Yu and H. J. Zhu, "Study on the pharmacological mechanism of Platycodon grandiflorum to treat bronchial asthma," Acta Chinese Medicine and Pharmacology, vol. 40, no. 3, pp. 38-40, 2012.

[64] H.-Y. Lee, G.-H. Lee, H.-K. Kim, and H.-J. Chae, "Platycodi radix and its active compounds ameliorate against house dust mite-induced allergic airway inflammation and ER stress and ROS by enhancing anti-oxidation," Food and Chemical Toxicology, vol. 123, pp. 412-423, 2019.

[65] Y. Xie, H. Pan, H. Sun, and D. Li, "A promising balanced Th1 and Th2 directing immunological adjuvant, saponins from the root of Platycodon grandiflorum," Vaccine, vol. 26, no. 31, pp. 3937-3945, 2008.

[66] Y. H. Zhang, J. Wang, H. L. Ruan et al., "Effect of verticinone and its derivatives on cyclic adenosine monophosphate of bronchus smooth muscle of Guinea-pig," Chinese Archives of Traditional Chinese Medicine, vol. 12, pp. 2484-2485, 2007.

[67] Y. Lin, X. e. Wang, and X. Yang, "The complete chloroplast genome and phylogenetic analysis of Fritillaria ussuriensis (Liliaceae: Fritillaria)," Mitochondrial DNA Part B, vol. 4, no. 1, pp. 2061-2062, 2019.

[68] X. Chen and Y. Huang, "Effects of Paeonia lactiflora extract on IL-22 and IL-13 levels in asthmatic rat models," Journal of Military Surgeon in Southwest China, vol. 15, no. 6, pp. 659-661, 2013.

[69] Q. Xin, R. Yuan, W. Shi, Z. Zhu, Y. Wang, and W. Cong, “A review for the anti-inflammatory effects of paeoniflorin in inflammatory disorders," Life Sciences, vol. 237, Article ID 116925, 2019.

[70] H. Zhou, Q. Wu, L. Wei, and S. Peng, "Paeoniflorin inhibits PDGF-BB-induced human airway smooth muscle cell growth and migration," Molecular Medicine Reports, vol. 17, pp. 2660-2664, 2018.

[71] L. T. M. Ngan, M. J. Jang, M. J. Kwon, and Y. J. Ahn, "Antiviral activity and possible mechanism of action of constituents identified in Paeonia lactiflora root toward human rhinoviruses," PLoS One, vol. 10, no. 4, Article ID e0121629, 2015.

[72] C. Qin, X. Dai, X. Q. Yang et al., "Intervention effect of honokiol on inflammatory response in lung tissue of asthma mice and its mechanism," Journal of Jilin University (Medicine Edition), vol. 46, no. 2, pp. 214-220+431, 2020.

[73] N. Liu, N. Li, L. Zhu et al., "Effect of honokiol on PI3K/Akt signaling pathway in asthmatic mice and its effect on TLR2 and TLR4 expression," Chinese Traditional and Herbal Drugs, vol. 50, no. 6, pp. 1407-1412, 2019.

[74] J. L. Shen, K. M. Man, P. H. Huang et al., "Honokiol and magnolol as multifunctional antioxidative molecules for dermatologic disorders," Molecules (Basel, Switzerland), vol. 15, pp. 6452-6465, 2010.

[75] H. Y. Luo, H. W. Wu, X. K. Yu et al., "A review of the phytochemistry and pharmacological activities of Magnoliae officinalis cortex," Journal of Ethnopharmacology, vol. 236, pp. 412-442, 2019.

[76] C. L. Wu, H. Y. Wang, J. Xu, J. Huang, X. Chen, and G. T. Liu, "Magnolol inhibits tumor necrosis factor- 
$\alpha$-induced ICAM- 1 expression via suppressing NF- $\kappa \mathrm{B}$ and MAPK signaling pathways in human lung epithelial cells," Inflammation, vol. 37, no. 6, pp. 1957-1967, 2014.

[77] C. Li, C.-J. Li, J. Ma et al., "Magmenthanes A-H: eight new meroterpenoids from the bark of Magnolia officinalis var. Biloba," Bioorganic Chemistry, vol. 88, Article ID 102948, 2019.

[78] E. X. Ou, "Effect of saikosaponin-d in treatment of cough variant asthma: an experimental study," Hunan Journal of Traditional Chinese Medicine, vol. 32, no. 6, pp. 172-174, 2016.

[79] T. T. Bui, C. H. Piao, C. H. Song, H. S. Shin, and O. H. Chai, "Bupleurum chinense extract ameliorates an OVA-induced murine allergic asthma through the reduction of the Th2 and Th17 cytokines production by inactivation of NF $\kappa \mathrm{B}$ pathway," Biomedicine \& Pharmacotherapy, vol. 91, p. 1085, 2017.

[80] C. Han, L. Yang, Q. L. Zhang et al., "Correlation study on baicalin's anti-asthmatic effects and HMGB1/TLR4 signal pathway," World Chinese Medicine, vol. 14, no. 6, pp. 1402-1407, 2019.

[81] C. Han, L. Yang, Q. L. Zhang et al., "Effect of baicalin on airway remodeling of bronchial asthma," Chinese Journal of Clinical Pharmacology and Therapeutics, vol. 22, no. 7, pp. 749-754, 2017.

[82] C. Han, L. Yang, Q. L. Zhang et al., "Influence of Baicalin on P38 MAPK signal pathways of rat asthma model," Guangzhou Medical Journal, vol. 47, no. 4, pp. 5-9, 2016.

[83] P. Wang, The Effect of Baicalin on the Imbalance of Th17/Treg Response in Mice with Allergic Asthma, YanBian University, Jilin, China, 2016.

[84] F. Huang, X. Y. Tong, H. M. Deng et al., "Primary study on mechanism of baicalin on the Th1/Th2 response in murine model of asthma," Journal of Chinese Medicinal Materials, vol. 32, no. 9, pp. 1407-1410, 2009.

[85] R. Xing, F. Guo, J. X. Tian et al., "Study on the effect of Scutellaria baicalensis on the pathogenesis of bronchial asthma in rats," Study Journal of Traditional Chinese Medicine, vol. 12, pp. 2097-2098, 2003.

[86] F. Liu, N.-X. Xuan, S.-M. Ying, W. Li, Z.-H. Chen, and H.-H. Shen, "Herbal medicines for asthmatic inflammation: from basic researches to clinical applications," Mediators of Inflammation, vol. 2016, Article ID 6943135, 12 pages, 2016.

[87] J. S. Ding, J. H. Li, X. L. Liu et al., "Preventive effect of Chinonin on Guinea pig's asthma and influence on ET and NO level," Chinese Journal of Traditional Medical Science and Technology, vol. 2, pp. 89-90+64, 2007.

[88] Y.-C. Lee, S.-H. Kim, Y.-B. Seo, S.-S. Roh, and J.-C. Lee, "Inhibitory effects of Actinidia polygama extract and cyclosporine A on OVA-induced eosinophilia and bronchial hyperresponsiveness in a murine model of asthma," International Immunopharmacology, vol. 6, no. 4, pp. 703-713, 2006.

[89] Y. Wei, H. Q. Tang, X. H. Li, and X. Y. Zhu, "Effects of loquat leaf injection on $\mathrm{T}$ lymphocyte subsets in asthma model mice," Journal of Emergency in Traditional Chinese Medicine, vol. 22, no. 7, pp. 1151-1152, 2013.

[90] Z. Q. Wu, Study on the Anti-allergic Effect and Mechanism of Different Extraction from Ramulus Cinnamomi, Chengdu University of T.C.M., Chengdu, China, 2015.

[91] X. Lv, G. Y. Xu, C. M. Wang et al., "Main targets and active components of schisandra chinensis for asthma treatment based on network pharmacology," Journal of Beihua University (Natural Science), vol. 21, no. 2, pp. 175-178, 2020.
[92] D. R. Wang, Y. T. Wang, S. Hua, and X. Y. Fan, "Effect of Schisandrin B on lung inflammation in asthmatic mice and its mechanism," Acta Universitatis Medicinalis Anhui, vol. 54, no. 5, pp. 735-740, 2019.

[93] X. Chen and J. Feng, "Effects of Schisandra chinensis extract on blood antioxidant activity of asthmatic model rats," China Pharmaceuticals, vol. 22, no. 23, pp. 25-27, 2013.

[94] H. Ahmed, "Ethnomedicinal, phytochemical and pharmacological investigations of Perilla frutescens (L.) britt," Molecules, vol. 24, no. 1, p. 102, 2019.

[95] Global Initiative for Asthma, Available from, Global Strategy for Asthma Management and Prevention, Global Initiative for Asthma, Geneva Lake, WI, USA, 2006, http://www. ginasthma.com.

[96] J. A. Zhang, J. Y. Li, X. D. An et al., "Analysis of the famous prescriptions of asthma in ancient and modern Chinese and Chinese," Chinese Journal of Information on TCM, vol. 8, pp. 34-35, 1997.

[97] T. B. Agbabiaka, N. H. Spencer, S. Khanom, and C. Goodman, "Prevalence of drug-herb and drug-supplement interactions in older adults: a cross-sectional survey," British Journal of General Practice, vol. 68, no. 675, pp. e711-e717, 2018.

[98] J. Lim, S. Chee, W. Wong, Q. He, and T. Lau, "Traditional Chinese medicine: herb-drug interactions with aspirin," Singapore Medical Journal, vol. 59, no. 5, pp. 230-239, 2018.

[99] Y. Chua, X. Ang, and X. M. Zhong, "Interaction between warfarin and Chinese herbal medicines," Singapore Medical Journal, vol. 56, no. 1, pp. 11-18, 2015.

[100] F. Cheng, X. Wang, W. Song et al., "Biologic basis of TCM syndromes and the standardization of syndrome classification," Journal of Traditional Chinese Medical Sciences, vol. 1, no. 2, pp. 92-97, 2014.

[101] L. Jiang, B. Liu, Q. Xie et al., "Investigation into the influence of physician for treatment based on syndrome differentiation," Evidence Based Complementary and Alternative Medicine, vol. 2013, Article ID 587234, 16 pages, 2013.

[102] L. Borish, "The immunology of asthma," Annals of Allergy, Asthma \& Immunology, vol. 117, no. 2, pp. 108-114, 2016.

[103] R. A.V, "Inhalational steroids and iatrogenic cushing's syndrome," The Open Respiratory Medicine Journal, vol. 8, no. 1, pp. 74-84, 2014.

[104] Y.-H. Yeh, Y.-J. Chou, N. Huang, C. Pu, and P. Chou, “The trends of utilization in traditional Chinese medicine in Taiwan from 2000 to 2010," Medicine, vol. 95, no. 27, p. e4115, 2016. 